УдК 316.36-043.7(470+571)

\title{
ТРАНСФОРМАЦИЯ ИНСТИТУТА СЕМЬИ В РОССИЙСКОМ ОБЩЕСТВЕ: СОЦИАЛЬНЫЕ ПРОТИВОРЕЧИЯ И СОЦИОЛОГИЧЕСКИЕ ИЛЛЮЗИИ
}

\author{
Вялых Никита Андреевич, \\ sociology4.1@yandex.ru \\ Южный федеральный университет, \\ Россия, 344006, г. Ростов-на-Дону, ул. Пушкинская, 160
}

\begin{abstract}
Вялых Никита Андреевич, кандидат социологических наук, докторант, доцент кафедры теоретической социологии и методологии региональных исследований Института социологии и регионоведения Южного федерального университета.
\end{abstract}

\begin{abstract}
Актуальность статьи обусловлена необходимостью преодоления существующих разночтений в понимании социальной сущности трансформации института семьи в современной российской социологии. Цель заключается в переоценке научно-исследовательских практик анализа структурных, ценностных и ролевых измерений брачно-семейных отношений. Новизна работы состоит в определении типичных иллюзий и противоречий, характерных для методологии социологического исследования брачно-семейных отношений. В первой части статьи раскрываются основные тенденции трансформации брачно-семейной сферы. В настоящее время прослеживается тенденция преодоления познавательной односторонности эволюционной и кризисной парадигм в попытке определения вектора социальных изменений семейного поведения в российском обществе. Вторая часть посвящена анализу социологического типа мышления в фамилистических исследованиях. Показано, что репрезентация семьи в виде ячейки институциональной матрицы является скорее методологической необходимостью, чем объективной реальностью. Особое внимание уделяется когнитивной установке многих ученых на социальную критику государственной семейной политики в России. Автор приходит к выводу о важности повышения роли личной ответственности в сфере благополучия и социального здоровья института семьи в современном российском обществе.
\end{abstract}

Ключевые слова: Институт семьи, трансформация, социология семьи, брачно-семейные отношения, государственная семейная политика, семейное поведение, российское общество.

\section{Введение}

На тему трансформации брачно-семейных отношений в современной российской социологии так много уже сказано и написано, что, кажется, и добавить уже нечего. Но это только при первом приближении значительная часть представителей профессионального социологического сообщества до сих пор пребывает в иллюзии существования общества как некой системы институтов, агрегирующей солидаристские практики. Единого мнения по поводу открытости или закрытости этой системы не сложилось, но «конвенция» об обязательном трансформационном характере российского общества и отдельных институтов уже давно достигнута и формализована в паспорте научной специальности 22.00.04 «Социальная структура, социальные институты и процессы (социологические науки)». Когнитивный интерес автора, написавшего большинство своих научных произведений именно в формате «04-й» специальности, к предметности трансформации института семьи в российском обществе обусловлен не столько противоречивым разновекторным развитием самой семьи как социокультурного феномена, сколько парадоксальной социологической реконструкцией социальных изменений в 
сфере брачно-семейных отношений, стирающей грань между мультипарадигмальностью и методологическим анархизмом. В результате оказывается, что разные социологи и региональные социологические школы живут в «разной» России. Цель нашего исследования заключается в переоценке социальной сущности трансформации института семьи в российском обществе как предмете научно-исследовательских практик современных социологов. Но для реализации этой «рефлексии над рефлексией» целесообразно сначала рассмотреть основные тенденции, которые просматриваются в развитии семьи и брака в российском социуме.

\section{Разновекторность трансформации института семьи в современном российском обществе}

А.В. Верещагина предлагает рассматривать трансформацию института семьи как преобразование «формальных и неформальных ограничений, в ходе взаимодействия которых происходит разрушение традиционного института семьи и возникновение нового современного института семьи, характеризующегося разнообразием и большим многообразием типов организации семейной жизни и семейного поведения» [1, с. 85]. Формальные и неформальные ограничения имеют социальную природу, но они постепенно теряют свою значимость и в процессе трансформации семьи актуализируются индивидуальные ограничения, имеющие отношение непосредственно к реальным семейным практикам [1, с. 88].

Представители ростовской социологической школы, опираясь на синергетическую парадигму, прогнозируют два сценария развития института семьи в России. Первый сценарий связан с сосуществованием различных типов семейных структур и форм брачно-семейных отношений, «начиная от традиционных (в тех регионах, характеризующихся большей устойчивостью традиционных семейных ценностей и норм), заканчивая различными альтернативными, не вписывающимися в формат традиционных, формами организации семейной жизни». Второй сценарий исследователи охарактеризовали как институционализацию современной семьи в качестве доминирующей (под влиянием процессов либерализации и эгалитаризации семейных ценностей), «которая со временем в процессе изменения формальных и неформальных ограничений (норм и правил) семейных отношений станет для данного социума традиционной, т. е. соответствующей традиционным представлениям общества о том, какой должна быть семья, ее структура, ценности, нормы и поведение (репродуктивное, демографическое, семейное)» $[2]$.

На конфигурацию социальных ролей мужчин и женщин в семье влияют социальная политика и гендерная идеология, зависящие от этнического и конфессионального состава регионального социума, а также этнической и конфессиональной принадлежности конкретного человека [3].

По мнению ученых, носителями эгалитарной семейной культуры, точнее ее элементов, являются преимущественно молодые семьи, более высокий уровень нестабильности которых может замедлить институционализацию модели эгалитарной семьи, уже сложившейся во многих регионах России и современного мира [4]. Однако процесс эволюции семьи динамичен, а значит, «перестройка традиционного института семьи в архаичном формате, не соответствующем динамике гендерных отношений, уже не угрожает институциональному пространству семьи» [5, с. 299].

Вместе с тем следует учитывать социокультурную опциональность как традиционного, так и современного типов семьи в пространстве российского общества. На материалах социологического обследования петербургских студентов О.Н. Бурмыкина 
выявила тенденцию сосуществования старых и новых явлений трансформации семьи и межпоколенческих отношений. К «старым» трендам социолог относит: неизолированность нуклеарной семьи от других родственных связей, симметрию моделей поведения и взаимозависимости, изменение направленности межпоколенческой поддержки; сохранение гендерного дисбаланса в поддержании межпоколенческих отношений; сохранение эмоциональной привязанности разных поколений членов семьи и сохранение конфликтов между поколениями в семье. Среди «новых» тенденций выделяются следующие: многообразие способов поддержки и взаимного влияния между разными поколениями семьи; расширение потенциального круга родственников; разнообразие и вариативность поведенческих предпочтений в межпоколенческих отношениях; замещение функций нуклеарной семьи [6].

Результаты эмпирических исследований Т.А. Гурко подтверждают ориентацию большинства студенческой молодежи на партнерскую модель ролевого взаимодействия супругов, что объясняется ежегодным увеличением доли женщин, имеющих высокие доходы и социальный статус, в социально-профессиональной структуре российского общества [7]. В целом семейное право в России диктует установку на эгалитарный тип брака и семьи. Конституция РФ и Семейный Кодекс РФ запрещают любые формы ограничения прав граждан при вступлении в брак и в семейных отношениях по признакам социальной, расовой, национальной, языковой или религиозной принадлежности.

А.В. Верещагина, В.В. Ковалев и С.И. Самыгин заставляют всерьез задуматься о зарождении нового цивилизационного витка матриархата. О становлении неоматриархального гендерного порядка свидетельствуют эгалитаризация семьи, понимаемая не просто как пресловутое равенство брачных партнеров, а как функциональная взаимозаменяемость мужчины и женщины вследствие усиления экономической независимости женщин, увеличения каналов социальной мобильности и возможностей самореализации для женщин. При этом становление женской субъектности и феминизация семейной сферы происходят в условиях пока еще мужского мира [8]. Г.Г. Силласте также пишет о том, что «Россия - страна с ярко выраженным женским лицом по гендерному паспорту и реальному портрету» [9, с. 61].

Одной из значимых тенденций трансформации семейной структуры является увеличение числа монородительских (неполных) семей. Причем, как отмечают Г.Л. Воронин и А.Л. Янак, сегодня распространено не только вынужденное монородительство (например, из-за расторжения брака, смерти одного из супругов и т. п.), но и монородительство как стратегия осознанного выбора. В рамках такого подхода неполные семьи можно рассматривать как самодостаточные семейные единицы или промежуточные между структурными изменениями этапа жизненного цикла семьи (например, между расторжением брака и заключением повторного) [10]. Следует отметить, что не все авторы считают концептуально корректным использование в научной литературе понятий «неполная семья» и «монородительская семья» как синонимичных и взаимозаменяемых. По мнению Н.А. Левой, термин «монородительская семья» является квазинаучным, поскольку «содержательная аморфность лишает его каких-либо смысловых коннотаций» в отличие от термина «неполная семья», самого по себе подразумевающего нежелательность подобной формы семьи, наличие некой социальной проблемы и гаммы сложностей, «с которыми сталкивается мать-одиночка, пытаясь совместить в себе одной два типа семейных ролей: традиционно мужские и традиционно женские» [11, с. 215].

Трансформация института семьи и брака в современном обществе обусловлена также динамикой потребностей и ценностей в сфере частной жизни, поскольку сексу- 
альная функция семьи, во-первых, все больше отделяется от репродуктивной ввиду широкого спектра методов предупреждения беременности, во-вторых, ослабевает сексуальная функция брака как основной формы социального контроля над отношениями между полами. Так, результаты социологических исследований экспертов ФНИСЦ РАН подтверждают толерантное отношение современной студенческой молодёжи к сексу до официального брака, а также смене нескольких сексуальных партнеров до момента заключения брака [12]. Анализируя такую форму брачно-семейных отношений как незарегистрированный фактический брак (сожительство), Е.Г. Лактюхина и Г.В. Антонов выявили в то же время достаточно высокую степень архаичности и традиционности представлений современных молодых пар о семье, проявляющихся прежде всего в подготовке к официальному браку и церемонии свадьбы как определенному компромиссу патриархального мира («собрать всех родственников», «как положено»), рыночного мира (уникальность платья, аксессуаров) и репутационного мира («не хуже чем у других», «на уровне») [13, с. 92].

Е.В. Котельникова и А.А. Нехороших на примере Японии показали, что даже в такой консервативной стране, если говорить о ценностях и традициях японского общества в брачно-семейной сфере, происходят кардинальные перемены: в условиях жесткого правового регулирования брачных союзов и социальной политики правительства по стимулированию гендерного равенства снижается мотивация к юридическому закреплению отношений и деторождению, остро встает вопрос об экономической доступности брака [14]. Что касается Франции, то она уже прошла эволюцию семейных ценностей, начиная «от ослабления традиционной семьи до утверждения ценностей индивидуальной самореализации и удовольствия» [15]. Одним из результатов этой эволюции является институционализированная практика заключения пактов гражданской солидарности (Pacte Civil de Solidarité), предоставляющих возможность юридического оформления имущественных отношений фактического союза двух людей (независимо от пола). Во Франции это своего рода правовая альтернатива официальному «полновесному» браку.

В России складывается парадоксальная реальность: вектор общественного саморазвития направлен в сторону либерализации семейных ценностей, а вектор государственной политики ориентирует нас на консервативный разворот. Концепция государственной семейной политики в РФ до 2025 г. предусматривает «проведение информационной кампании по повышению общественного престижа семейного образа жизни, многодетности и многопоколенной семьи путем создания специальных телевизионных передач и радиопередач, ток-шоу, газетных и журнальных рубрик, иных информационных проектов, популяризирующих традиционные семейные ценности и способствующих формированию позитивного отношения к браку, родительству, достойному отношению к старшему поколению и родному дому» [16, с. 16].

Трансформационный кризис, если мы признаем все-таки его наличие, института семьи и брака имеет глубокие социокультурные основания. Он возникает как бы на стыке ментальности и институциональности современного российского общества. Ваяние образа (модели) института семьи и адресная материальная поддержка семьи - взаимосвязанные, но все же разные элементы семейной и демографической политики. Издержки трансформации института современной российской семьи связаны с нечетким видением на уровне государственной семейной политики предпочтительного институционального типа семьи. Отсюда вытекает непонимание, какие следует использовать инструменты государственной политики (и следует ли вообще) для гармонизации сосуществования различных институциональных типов семьи [2]. К тому же у каждой 
социально-территориальной общности будет свой социальный портрет традиционного и современного типов семьи. Следовательно, любые попытки социального конструирования на национальном уровне модели семьи с традиционными ценностями как наиболее предпочтительной для российского общества обречены на провал. Да и вряд ли это вообще возможно и целесообразно навязывать обществу определенные нормы и стандарты демографического и семейного поведения. Только посредством политики «мягкой силы» можно поощрять и стимулировать приоритетные для развития социума (хотя бы в масштабе субъектов РФ) формы брачно-семейного поведения.

\section{Искажения социологической рефлексии трансформационных процессов в сфере брачно-семейных отношений}

Исторически в социологии наблюдается борьба номинализма и реализма в попытках определения общества и выявления социальных закономерностей. Впрочем, есть и «центристы», которые в соответствии с нынешней познавательной модой выстраивают гибридные методологические конструкции, сочетающие в себе сильные стороны классической и неклассической социологии. Наиболее приемлемым объектом для социологических исследований в контексте идеи методологической полипарадигмальности оказывается семья. Однако в ходе социологической сборки интеллектуальных объектов в сфере познания динамики брачно-семейных отношений зачастую возникают иллюзии и противоречия. Их мы и обсудим в данном разделе статьи.

Социологический тип мышления основан на раздвоении предметной области фамилистических исследований, потому что семья комбинирует признаки социального института и малой социальной группы. В попытке научной рефлексии дуальности факторов институционального и поведенческого уровней сферы семейно-брачных отношений, социальной структуры семьи и в то же время места семьи в социальной структуре общества и выражается специфика социологического ракурса, отличающего его от других дисциплинарных подходов. [17]. Но если посмотреть на повседневную реальность глазами, не вооруженными социологической оптикой, то никаких институтов, в частности института семьи, мы не обнаружим. Социологами ежегодно проводятся десятки и сотни исследований брачно-семейных отношений, но почему-то никто никогда не спросил респондентов, осознают ли они институциональную природу своей семейности и свой функциональный потенциал по отношению к обществу. Сомнительно, что люди, создающие семейные группы, имеют целью реализовать общественно значимые функции воспроизводства популяции, социального контроля, экономической поддержки, трансмиссии социального статуса. Первичным мотивом образования семьи являются индивидуальные биопсихосоциальные потребности человека, базирующиеся на иерархическом, половом и самосохранительном инстинктах.

По факту социальный институт семьи - это «замок на песке», мысленный конструкт, обретающий себя в языковых играх ученых и политиков. Само по себе это не плохо и не хорошо. Еще П. Бурдье говорил о латентном притязании социологов на символическую власть посредством использования специфического языка и манипулирования социологическими данными. «Сакральное» социологическое знание создает иллюзию возможности идеологического контроля семейной культуры и управления семейным поведением населения. Социологи оперируют понятием института для упрощения моделирования карт социальной действительности, а карта реальности не может и не должна быть самой реальностью. Ведь и в географических атласах нет ни рек, ни гор, ни деревьев, ни тем более людей, населяющих административнотерриториальные образования. Репрезентация общества в виде институциональной 
матрицы является всего лишь методологической необходимостью, позволяющей типизировать жизненный мир и выявить скрытые закономерности человеческого поведения.

Миссия социологии семьи как учебной дисциплины, научной области и институциональной управленческой практики состоит в создании когнитивной ситуации, помогающей людям со стороны взглянуть на свою собственную семью, семьи друзей и близких, реконструировать различные модели брачно-семейных отношений для переосмысления своего жизненного опыта и проектирования стратегии семейного поведения. В этом заключается главный, пусть и весьма скромный по масштабу, идеологический потенциал социологии семьи, когда сами социологи и все, хоть как-то знакомые с научными достижениями в этой области знания, очищают мышление от предрассудков, стереотипов, повышая свои шансы на счастливый брак, в котором счастливые дети вырастут счастливыми и успешными взрослыми.

В условиях плюрализации форм брачно-семейных отношений и увеличения числа неблагополучных семей ослабевает значение семьи как социального института и вместе с тем возрастает ее роль как малой социальной группы, в которой реализуются интересы и потребности личности [1]. В современном российском обществе, как отмечают фамилисты, брачные союзы в основном заключаются ради совместного достижения успеха и психологической поддержки друг друга, обретения чувства спокойствия и социальной защищенности, а не из прагматических соображений, как это было на ранних этапах институционализации брака $[18,19]$.

М.С. Горяев и Б.А. Оконов, анализируя проблемы трансформации семьи и брака в русле отечественной историографии, пришли к выводу о том, что институт семьи в современном российском обществе не претерпевает кризис, а находится на переходном этапе эволюционного развития, испытывая новые формы организации брачносемейных отношений и модели семейного поведения в условиях динамики общественного устройства и ценностей культуры [20, с. 87]. Схожей позиции придерживается Д.В. Галкина, аргументируя свою точку зрения тем, что кризис семьи представляет собой крайнее обострение противоречий в ней как в системе, угрожающее ее жизнестойкости в окружающей среде, поэтому «вести речь о кризисе семьи как социального института неправомерно, т. к. семья относится к наиболее устойчивым социальным структурам, наряду с языком и религией, которые не меняются существенным образом при смене формаций, при социальных трансформациях и катаклизмах» [21, с. 110].

Как правило, кризисный и эволюционный подходы к изучению трансформации семьи противопоставляются. А.В. Верещагина и С.И. Самыгин предлагают иной методологический подход, нивелирующий противостояние кризисной и эволюционной парадигм, благодаря которому открывается возможность исследования институциональных изменений в семейной сфере в контексте разрушения традиционных и появлении новых семейных институтов в русле исторической траектории российского общества, в которой тот или иной институциональный выбор в настоящей реальности обусловливается прошлым [2].

Компромиссной позицией в дискуссии представителей эволюционного и кризисного подходов является признание ряда дисфункциональных явлений, которые на данный момент не угрожают жизнеспособности институциональных основ брачносемейных отношений ввиду их высокой необходимости как на уровне общества и государства, так и на личностно-индивидуальном уровне. Не исключено, что в настоящее время есть кризис института семьи, но нет кризиса семьи как отдельной малой социальной группы, либо наоборот, мы можем в повседневной реальности встретить отдельные кризисные семьи, но семья как социальный институт может быть вполне 
функциональным. Индуктивный метод зачастую приводит социологов к искаженным и поспешным заключениям, т. к. совокупность частей целого не определяет автоматически сущностные характеристики всего целого.

Таким образом, кризис института семьи - это не более чем познавательнооценочный лейбл (как и сам институт семьи), оправдывающий научноисследовательскую и прикладную интервенцию социологов-семьеведов. Как и профессиональное медицинское сообщество, сообщество социологов негласно заинтересовано в «болезнях» социума. Если даже эти заболевания не носят выраженного характера, то любые состояния и социальные процессы всегда можно «проблематизировать» инструментами социологической диагностики.

В настоящее время речь идет скорее о перенастройке структурных, ценностных и ролевых измерений брачно-семейной сферы [22]. Так, Е.А. Капогузов, Р.И. Чупин и М.С. Харламова считают, что преобладание в обществе современных форм семейных отношений по мере трансформации института семьи является логичным следствием расширения возможностей выбора, усиления территориальной мобильности индивидов, развития цифровых технологий коммуникации, повышения гибкости законодательства в сфере семьи и брака [23]. Среди парадоксов трансформации постсовременной семьи все чаще исследователями упоминается переход от патриархальной субординации к гендерно-ролевому конфликту, вследствие которого размываются нормы, детерминирующие маскулинное и феминное взаимодействие, а на первый план жизненных стратегий личности выходят эмоциональные потребности и индивидуализация [24].

В социологических исследованиях большое внимание уделяется анализу семьи в пространстве социальной политики государства. Такие научные публикации обыкновенно начинаются и заканчиваются критическими замечаниями в адрес агентов, ответственных за реализацию государственной семейной политики. В подобных работах часто встречаются семантические конструкции «государство обязано», «правительство должно обеспечить», «надо принять закон» и т. п.

Иногда социальная критика государства по поводу недостаточного внимания к институту семьи носит слепонемой характер. Правительство страны проводит достаточно осмысленную и взвешенную политику, направленную на социальную поддержку семей даже в условиях экономического кризиса, вызванного сложной эпидемиологической ситуацией. Также нельзя не отметить последовательную реализацию интересов демографического развития российского общества. Среди установленных на федеральном уровне мер социальной поддержки семей особенно хочется выделить следующие: ежемесячные выплаты в связи с рождением или усыновлением первого или второго ребенка; бюджетные ассигнования на поддержку семей при рождении детей на Дальнем Востоке; предоставление многодетным семьям земельных участков под индивидуальное жилищное строительство; субсидирование процентной ставки по ипотечным кредитам для семей с детьми; развитие и повышение доступности системы присмотра и ухода за маленькими детьми, дошкольного воспитания и образования; продление и расширение программы материнского (семейного) капитала, средства которого можно направить на улучшение жилищных условий, приобретение жилья, образовательные услуги для детей, накопительную пенсию матери, приобретение товаров и услуг, предназначенных для социальной адаптации и интеграции в общество детей-инвалидов $[25,26]$.

Поскольку возможности экономической поддержки семей и финансовых механизмов стимулирования многодетности небезграничны, государство поощряет формы занятости, позволяющие людям с высокой семейной нагрузкой совмещать работу с выполнением семейных обязанностей (занятость на условиях неполного рабочего време- 
ни, работа по гибкому графику или на дому, семейное предпринимательство и фермерство) [16]. В последние годы активно развивается система социальных контрактов между гражданами (семьями) и органами социальной защиты населения, предполагающие оказание социальной помощи семьям, находящимся в трудной жизненной ситуации. Однако эта помощь носит не односторонний характер, а предполагает четко оговоренные контрактом обязательства граждан, конкретные виды вмешательства или методы работы, временные рамки совместной деятельности [27].

Проблема реализации программных мероприятий скорее кроется в правоприменительной практике в отношении нуждающихся семей, территориальных различиях и информационной неосведомленности населения о льготах и преференциях [28, 29]. До сих пор бытует заблуждение о семье как «объекте» государственной политики. Семья является не столько объектом государственной помощи и поддержки, сколько субъектом равноправного взаимодействия и взаимной ответственности общества перед семьей и семьи перед обществом. В противном случае существует риск формирования подхода, при котором социальные проблемы семьи редуцируются к проблемам отдельных индивидов (престарелым, больным, недееспособным и т. д.), т. е. семья станет восприниматься как «потенциальный больной», «пациент» различного рода социальных служб [30, с. 111]. Поэтому перспектива развития института семьи в России связывается в первую очередь «с концепцией самоорганизующейся и успешной семьи, которая свои проблемы решает за счет мобилизации своего материального и духовного потенциала» [31, с. 195].

\section{Выводы}

Реализуя функции социальной общности, семья отражает три основные сферы социальных отношений: индивидуальные, групповые, социетальные [32]. Структурнофункциональные сдвиги в каждой из обозначенных социальных проекций позволяют одним ученым говорить о кризисе семьи как социального института, другим - об усложнении брачно-семейных отношений в соответствии с естественным историческим процессом («эволюционный подход»), третьим - «умеренным консерваторам» от науки - о точках напряженности в брачно-семейной сфере, которые при условии успешной реализации задач семейной политики государства не повлияют существенным образом на системообразующую роль семьи в поддержании социальной стабильности российского общества. Несмотря на констатацию семьеведами кризисных состояний института брака и семьи, самые пессимистичные прогнозы разрушения семейных форм организации социокультурного взаимодействия, семья продолжает существовать [33].

В условиях трансформации российского общества формируется традиционномодернистский тип семьи, который комбинирует признаки традиционной и современной семьи. Данный тип является не просто гибридным, а скорее переходной моделью брачно-семейных отношений, институционализация которой едва ли возможна [1]. В зависимости от того, в какую сторону качнется маятник социальных настроений, ожиданий, потребностей общества, государственной семейной политики и функционирования различных социальных институтов, будет доминировать тот или иной тип семьи. Ни одна инновация не остается инновацией бесконечно, равно как и ни одна традиция не может быть традицией искони. Следовательно, современный тип семьи (для каждого общества и региона он будет специфичен) имеет все шансы на определенном этапе исторического развития брачно-семейных отношений стать традиционным [1].

Решение кризисных состояний института семьи во многом сводится к проведению активной демографической политики, направленной на снижение смертности, по- 
вышение показателей ожидаемой продолжительности жизни и стимулирование рождаемости. Воспроизводство популяционных и трудовых ресурсов сейчас очень востребовано для развития российского общества, однако следует уделять равноценное внимание достижению высоких стандартов качества жизни семей. Гонка за позитивной динамикой количественных показателей может только увеличить риск антропологической катастрофы. К тому же, наряду с общими демографическими тенденциями, характерными для России в целом, имеются значительные различия между субъектами РФ, что обусловливает необходимость дифференцированного подхода к разработке и реализации региональных демографических программ [34].

Государство достаточно оперативно и адекватно реагирует на вызовы и угрозы современной семье в России. Это выражается в системности приоритетов и задач государственной семейной и демографической политики, широком наборе инструментов материальной поддержки нуждающихся семей. Однако реализуемые программные мероприятия существенно не влияют на модели (типы) семьи, которые формируются стихийно под воздействием внешних и внутренних факторов. Да и можно ли, и правомерно ли на уровне государственной семейной политики оказывать влияние на социальнопсихологические механизмы брачно-семейных отношений? Теоретически это, конечно, возможно. Но прежде чем реализовать меры интенсивного развития общества, нужно достичь целевых показателей экстенсивного развития, обозначенных в концепциях семейной и демографической политики, а также в стратегии развития здравоохранения в России. В действительности, даже с учетом внушительного объема конкретносоциологических исследований семьи и брака в современной России ученые сталкиваются практически всегда с дефицитом информации, поскольку семья - закрытое пространство, а значит, доступ ко многим аспектам функционирования ее жизненных циклов строго ограничен [35].

В условиях трансформации базовых институтов общества следует помнить о повышении роли личной ответственности семьи за свое благополучие и здоровье во всех его измерениях (социальном, психологическом, духовном, физическом). Социологам и гуманитариям, которые с академических амвонов твердят о необходимости усиления государственного контроля и участия в сфере брачно-семейных отношений, о значимости увеличения финансирования по ряду направлений социальной политики, нужно оставаться реалистами. Дело в том, что нельзя просто включить «печатный станок» и вмиг всех желающих обеспечить бесплатным спортом и образованием, доступным здравоохранением, демократичным жильем, высокооплачиваемой работой, интересным досугом, социальными преференциями. Социальная критика процессов в сфере брачносемейных отношений должна быть предельно конструктивной, а научные рекомендации - не только отвечать на вопрос что нужно делать для позитивных сдвигов, но и как нужно это делать и зачем. Людям же, образующим семьи, остается только посоветовать действовать не только «с позиции права» по отношению к социальным гарантиям государства, но и учитывать свои обязательства, зону персональной ответственности за жизненный мир новой семьи и динамику ее жизненного цикла.

\section{СПИСОК ЛИТЕРАТУРЫ}

1. Верещагина А.В. Институциональные изменения в семейной сфере и демографические перспективы России: методологическая матрица исследования // Гуманитарий Юга России. - 2012. - № 4. - С. 82-93.

2. Верещагина А.В., Самыгин С.И. Кризис традиционной семьи и альтернативы развития института семьи в России: теоретический анализ с позиций синергетической парадигмы // Инженерный вестник Дона. - 2014. - № 3 (30). - С. 68-71. 
3. Гурко Т.А., Мамиконян М.С., Бийжанова Э.К. Исследования гендерной идеологии молодежи: обзор зарубежных работ // Социология медицины. - 2018. - № 17 (2). - С. 104-113.

4. Institutional space of a family in the South of Russia: specificity of traditions and innovations / K.S. Chikaeva, A.V. Rachipa, E.V. Motsovkina, L.O. Ilina, M.V. Ivanov, E.M. Zagirova, Ya.V. Artamonova // Revista San Gregorio. - 2019. - № 34. - P. 127-137.

5. Загирова Э.М. Традиции и инновации в институциональном пространстве дагестанской семьи // Известия Саратовского университета. Новая серия. Серия «Социология. Политология». - 2017. Т. 17. - Вып. 3. - С. 298-303.

6. Бурмыкина О.Н. Тенденции изменений межпоколенных семейных отношений // Петербургская социология сегодня. - 2019. - № 12. - С. 134-153.

7. Гурко Т.А. Представления студентов в отношении родительства и социальных ролей мужчин и женщин // Социологическая наука и социальная практика. - 2019. - Т. 7. - № 2. - С. 65-80.

8. Верещагина А.В., Ковалев В.В., Самыгин С.И. Неоматриархат в условиях кризиса патриархальной семьи: становление новой гендерной картины мира // Гуманитарные, социально-экономические и общественные науки. - 2018. - № 3. - С. 13-18.

9. Силласте Г.Г. От решения женского вопроса к новому гендерному порядку: движение в модусах социального времени // Гуманитарий Юга России. - 2017. - Т. 6. - № 5. - С. 48-62.

10. Воронин Г.Л., Янак А.Л. Монородительские семьи: их типы и социальный портрет одинокого родителя // Женщина в российском обществе. - 2018. - № 1 (86). - С. 53-66.

11. Левая Н.А. Неполная семья как фактор социальной нестабильности социума // Социальная политика и социология. - 2014. - Т. 2. - № 3 (104). - С. 211-221.

12. Тарченко В.С. Поведение и установки студентов в сфере сексуальных отношений // Вестник Нижегородского университета им. Н.И. Лобачевского. Серия «Социальные науки». - 2019. - № 4 (56). C. $159-164$.

13. Лактюхина Е.Г., Антонов Г.В. «Мы просто живем вместе»: сожительство в современной России // Журнал социологии и социальной антропологии. - 2015. - Т. 18. - № 4. - С. 82-95.

14. Котельникова Е.В., Нехороших А.А. Трансформация института семьи в современной Японии // Аллея науки. - 2019. - Т. 2. - № 4 (31). - С. 295-298.

15. Ячменева М.В. Эволюция семейных ценностей во Франции и ее влияние на современные социальные практики молодежи // Мир науки. Социология, филология, культурология. URL: https://sfkmn.ru/PDF/54SCSK419.pdf (дата обращения 03.01.2021).

16. Об утверждении Концепции государственной семейной политики в Российской Федерации на период до 2025 года: распоряжение Правительства РФ от 25.08.2014 № 1618-p. URL: http://government.ru/docs/14494 (дата обращения 02.01.2021).

17. Вялых Н.А. Социология семьи в России: методологические проекции и современные научноисследовательские практики // Векторы благополучия: экономика и социум. - 2020. - № 3 (38). C. $53-65$.

18. Лунева Е.В., Кивелев Д.П., Брызгалова О.Н. Институт семьи: тенденции трансформации в современных российских условиях // Вестник Шадринского государственного педагогического университета. - 2019. - № 2 (42). - С. 72-77.

19. Сомкин А.А., Данилова О.А. Трансформация понятий «семья» и «брак» в современном российском обществе // Гуманитарий: актуальные проблемы гуманитарной науки и образования. - 2018. T. 18. - № 2 (42). - С. 205-219.

20. Горяев М.С., Оконов Б.А. Проблемы трансформации семьи и брака в отечественной историографии // Вестник Института комплексных исследований аридных территорий. - 2017. - Т. 2. - № 2 (35). C. $84-88$.

21. Галкина Д.В. Трансформация современной российской семьи, ее структурные и функциональные проявления // Историческая и социально-образовательная мысль. - 2015. - Т. 7. - № 7-2. - С. 109-113.

22. Терскова С.Г. Некоторые аспекты трансформации института семьи и брака // Аллея науки. - 2019. T. 2. - № 12 (39). - С. 129-132.

23. Капогузов Е.А., Чупин Р.И., Харламова М.С. Институциональные арены брачных игр // Journal of Institutional Studies. - 2019. - T. 11. - № 4. - С. 26-39.

24. Кононова Т.М., Акулич Е.М., Ситёва С.С. Парадоксы маскулинной социализации: от патриархата к гендерно-ролевому конфликту // Вестник Сургутского государственного педагогического университета. - 2019. - № 2 (59). - С. 33-40.

25. Демография. Семья и дети // Официальный портал Правительства PФ. URL: http://government.ru/rugovclassifier/section/2464/ (дата обращения 03.01.2021). 
26. О дополнительных мерах государственной поддержки семей, имеющих детей: федер. закон от 29.12.2006 № 256-Ф3 (ред. от 02.08.2019). URL: http://www.consultant.ru/document/ cons_doc_LAW_64872/5b387355ab19399172e9285519334e1efb84ea37 (дата обращения 03.01.2021).

27. Жизненные миры современной российской семьи / З.Х. Саралиева, В.А. Блонин, Н.Ю. Егорова и др. - Н. Новгород: Изд-во ННГУ, 2015. - 264 с.

28. Шалин В.В., Панченко А.А. Трансформация модели многодетной семьи как основного элемента устойчивого развития страны // Теория и практика общественного развития. - 2019. - № 4 (134). C. 13-23.

29. Берестова Л.И., Ярославцева Т.А. Социальная политика и социально-экономическая защищенность многодетных семей в регионах Дальнего Востока // Власть и управление на Востоке России. 2016. - № 4 (77). - С. 62-75.

30. Новосёлова Е.Н. Равенство институтов семьи и государства как необходимое условие преодоления глобального демографического кризиса // Вестник Московского университета. Серия 18. Социология и политология. - 2014. - № 2. - С. 108-118.

31. Немова О.А., Вагин Д.Ю., Тростин В.Л. Российская семья на пороге нового десятилетия - проблемы и варианты развития // Проблемы современного педагогического образования. - 2019. - № 65-2. C. 193-195.

32. Пьянов А.И. Семья как объект и предмет социологического анализа // Известия Российского государственного педагогического университета им. А.И. Герцена. - 2011. - № 132. - С. 169-179.

33. Шихова Е.П. Новые междисциплинарные акценты в социологии: семья на этапе ожидании ребенка // Вестник Тихоокеанского государственного университета. - 2015. - № 1 (36). - С. 287-294.

34. Об утверждении Концепции демографической политики Российской Федерации на период до 2025 года: указ Президента РФ от 09.10.2007 № 1351 (ред. от 01.07.2014). URL: http://www.consultant.ru/document/cons_doc_LAW_71673 (дата обращения 04.01.2021).

35. Бартуль Е.С. Исследование супружеских конфликтов на разных этапах жизненного цикла семьи // Международный студенческий научный вестник. - 2019. - № 4. URL: http://eduherald.ru/ru/article/view?id=19693 (дата обращения: 04.01.2021).

Поступила 06.01.2021 г. 
UDC 316.36-043.7(470+571)

\title{
FAMILY INSTITUTE TRANSFORMATION IN RUSSIAN SOCIETY: SOCIAL CONTRADICTIONS AND SOCIOLOGICAL ILLUSIONS
}

\author{
Nikita A. Vyalykh, \\ sociology4.1@yandex.ru \\ Southern Federal University, \\ 160, Pushkinsky avenue, Rostov-on-Don, 344006, Russia
}

Nikita A. Vyalykh, Cand. Sc., doctoral candidate, associate professor, Southern Federal University.

The relevance of the article is determined by the need to overcome the existing differences in understanding the social essence of the family institute transformation in Russian sociology today. The aim of the article is a revision of research practices of analysis of structural, value and role dimensions of marriage and family relations. The novelty of the work is in identifying the common illusions and contradictions, typical for the sociological research methodology of marriage and family relations. The paper consists of two main parts. In the first part the basic trends in marriage and family sphere transformation are revealed. Currently, there is a tendency to overcome the cognitive one-sidedness of evolution and crisis paradigms in an attempt to determine a vector of social changes in family behavior in Russian society. The second part deals with sociological type of thinking in the field of family studies. It is showed that the family representation as a cell of the institutional matrix is a methodological necessity but not objective reality. A special attention is given to the cognitive attitude of many scientists to social criticism of governmental family policy in Russia. The author comes to the conclusion about the importance of personal responsibility role increase in the sphere of family institute well-being and social health in modern Russian society.

Key words: Family institute, transformation, sociology of the family, marriage and family relations, governmental family policy, family behavior, Russian society.

\section{REFERENCES}

1. Vereshchagina A.V. Institutsionalnye izmeneniya v semeynoy sfere i demograficheskie perspektivy Rossii: metodologicheskaya matritsa issledovaniya [Institutional changes in the family sphere and demographic prospects of Russia: methodological matrix of the research]. Gumanitariy Yuga Rossii, 2012, no. 4, pp. 82-93.

2. Vereshchagina A.V., Samygin S.I. Krizis traditsionnoy semi i alternativy razvitiya instituta semi v Rossii: teoreticheskiy analiz s pozitsiy sinergeticheskoy paradigmy [The crisis of the traditional family and alternatives to the development of the family institution in Russia: a theoretical analysis from the perspective of the synergetic paradigm]. Inzhenerny vestnik Dona, 2014, no. 3, pp. 68-71.

3. Gurko T.A., Mamikonyan M.S., Biyzhanova E.K. Issledovaniya gendernoy ideologii molodezhi: obzor zarubezhnykh rabot [Studies of the gender ideology of youth: a review of foreign works]. Sotsiologiya meditsiny, 2018, no. 17 (2), pp. 104-113.

4. Chikaeva K.S., Rachipa A.V., Motsovkina E.V., Ilina L.O., Ivanov M.V., Zagirova E.M., Artamonova Ya.V. Institutional space of a family in the South of Russia: specificity of traditions and innovations. Revista San Gregorio, 2019, no. 34, pp. 127-137.

5. Zagirova E.M. Traditsii i innovatsii $\mathrm{v}$ institutsionalnom prostranstve dagestanskoy semi [Traditions and innovations in the institutional space of the Dagestani family]. Izvestiya Saratovskogo universiteta. Novaya seriya. Seriya «Sociologiya. Politologiya», 2017, vol. 17, no. 3, pp. 298-303.

6. Burmykina O.N. Tendentsii izmeneniy mezhpokolennykh semeynykh otnosheniy [Trends in intergenerational family relations]. Peterburgskaya sotsiologiya segodnya, 2019, no. 12, pp. 134-153.

7. Gurko T.A. Predstavleniya studentov v otnoshenii roditelstva i sotsialnykh roley muzhchin i zhenshchin [Students' perceptions of parenthood and the social roles of men and women]. Sotsiologicheskaya nauka $i$ sotsialnaya praktika, 2019, vol. 7, no. 2, pp. 65-80. 
8. Vereshchagina A.V., Kovalev V.V., Samygin S.I. Neomatriarkhat v usloviyakh krizisa patriarkhalnoy semi: stanovlenie novoy gendernoy kartiny mira [Neo-patriarchy in the context of the patriarchal family crisis: the formation of a new gender picture of the world]. Gumanitarnye, sotsialno-ekonomicheskie $i$ obshchestvennye nauki, 2018, no. 3, pp. 13-18.

9. Sillaste G.G. Ot resheniya zhenskogo voprosa k novomu gendernomu poryadku: dvizhenie v modusakh sotsialnogo vremeni [From the solution of the women's question to the new gender order: movement in the modes of social time]. Gumanitariy Yuga Rossii, 2017, vol. 6, no. 5, pp. 48-62.

10. Voronin G.L., Yanak A.L. Monoroditelskie semi: ikh tipy i sotsialny portret odinokogo roditelya [Singleparent families: their types and social portrait of a single parent]. Zhenshchina $v$ rossiyskom obshchestve, 2018, no. 1 (86), pp. 53-66.

11. Levaya N.A. Nepolnaya semya kak faktor sotsialnoy nestabilnosti sotsiuma [Incomplete family as a factor of social instability of society]. Sotsialnaya politika i sotsiologiya, 2014, vol. 2, no. 3 (104), pp. 211-221.

12. Tarchenko V.S. Povedenie i ustanovki studentov v sfere seksualnykh otnosheniy [Behavior and attitudes of students in the field of sexual relations]. Vestnik Nizhegorodskogo universiteta im. N.I. Lobachevskogo. Seriya «Sotsialnye nauki», 2019, no. 4 (56), pp. 159-164.

13. Laktykuhina E.G., Antonov G.V. «My prosto zhivem vmeste»: sozhitelstvo v sovremennoy Rossii [«We just live together»: cohabitation in modern Russia]. Zhurnal sotsiologii $i$ sotsialnoy antropologii, 2015, vol. 18 , no. 4 , pp. $82-95$.

14. Kotelnikova E.V., Nekhoroshikh A.A. Transformatsiya instituta semi v sovremennoy Yaponii [Transformation of the family Institution in modern Japan]. Alleya nauki, 2019, vol. 2, no. 4 (31), pp. 295-298.

15. Yachmeneva M.V. Evolyutsiya semeynykh tsennostey vo Frantsii i ee vliyanie na sovremennye sotsialnye praktiki molodezhi [Evolution of family values in France and its impact on modern social practices of young people]. Mir nauki. Sotsiologiya, filologiya, kulturologiya. Available at: https://sfkmn.ru/PDF/54SCSK419.pdf (accessed 3 January 2021).

16. Ob utverzhdenii Kontseptsii gosudarstvennoy semeynoy politiki v Rossiyskoy Federatsii na period do 2025 goda [On approval of the Concept of State family Policy in the Russian Federation for the period up to 2025]. Rasporyazhenie Pravitelstva RF ot 25.08.2014 no. 1618-r [Order of the Government of the Russian Federation of 25.08.2014 no. 1618-r]. Available at: http://government.ru/docs/14494 (accessed 3 January 2021).

17. Vyalykh N.A. Sotsiologiya semi v Rossii: metodologicheskie proektsii i sovremennye nauchnoissledovatelskie praktiki [Sociology of the family in Russia: methodological projections and modern research practices]. Vektory blagopoluchiya: ekonomika i sotsium, 2020, no. 3 (38), pp. 53-65.

18. Luneva E.V., Kivelev D.P., Bryzgalova O.N. Institut semi: tendentsii transformatsii v sovremennykh rossiyskikh usloviyakh [The institution of family: trends of transformation in modern Russian conditions]. Vestnik Shadrinskogo gosudarstvennogo pedagogicheskogo universiteta, 2019, no. 2 (42), pp. 72-77.

19. Somkin A.A., Danilova O.A. Transformatsiya ponyatiy «semya» i «brak»v sovremennom rossiyskom obshchestve [Transformation of «family» and «marriage» concepts in modern Russian society]. Gumanitariy: aktualnye problemy gumanitarnoy nauki i obrazovaniya, 2018, vol. 18, no. 2 (42), pp. 205-219.

20. Goryaev M.S., Okonov B.A. Problemy transformatsii semi i braka v otechestvennoy istoriografii [Problems of family and marriage transformation in Russian historiography]. Vestnik Instituta kompleksnykh issledovaniy aridnykh territoriy, 2017, vol. 2, no. 2 (35), pp. 84-88. In Rus.

21. Galkina D.V. Transformatsiya sovremennoy rossiyskoy semyi, ee strukturnye i funktsionalnye proyavleniya [Transformation of the modern Russian family, its structural and functional manifestations]. Istoricheskaya $i$ sotsialno-obrazovatelnaya mysl, 2015, vol. 7, no. 7-2, pp. 109-113.

22. Terskova S.G. Nekotorye aspekty transformatsii instituta semi i braka [Some aspects of the transformation of the institution of family and marriage]. Alleya nauki, 2019, vol. 2, no. 12 (39), pp. 129-132.

23. Kapoguzov E.A., Chupin R.I., Kharlamova M.S. Institutsionalnye areny brachnykh igr [Institutional mating arenas]. Journal of Institutional Studies, 2019, vol. 11, no. 4, pp. 26-39. In Rus.

24. Kononova T.M., Akulich E.M., Siteva S.S. Paradoksy maskulinnoy sotsializatsii: ot patriarkhata k genderno-rolevomu konfliktu [Paradoxes of masculine socialization: from patriarchy to gender-role conflict]. Vestnik Surgutskogo gosudarstvennogo pedagogicheskogo universiteta, 2019, no. 2 (59), pp. 33-40.

25. Demografiya. Semya i deti [Demography. Family and children]. Ofitsialny portal Pravitelstva RF. Available at: http://government.ru/rugovclassifier/section/2464/ (accessed 3 January 2021).

26. O dopolnitelnykh merakh gosudarstvennoy podderzhki semey, imeyushchikh detey [On Additional Measures of State support for Families with children]. Federalny zakon ot 29.12.2006 no. 256-FZ (red. ot 02.08.2019) [Federal Law No. 256-FZ of 29.12.2006 (amended 02.08.2019)]. Available at: http://www.consultant.ru/document/cons_doc_LAW_64872/5b387355ab19399172e9285519334e1efb84ea3 7/ (accessed 3 January 2021). 
27. Saralieva Z.H., Blonin V.A., Egorova N.Yu. Zhiznennye miry sovremennoy rossiyskoy semi [Life worlds of the modern Russian family]. N. Novgorod, NNGU Publ., 2015. 264 p.

28. Shalin V.V., Panchenko A.A. Transformatsiya modeli mnogodetnoy semyi kak osnovnogo elementa ustoychivogo razvitiya strany [Transformation of the model of a large family as the main element of sustainable development of the country]. Teoriya i praktika obshchestvennogo razvitiya, 2019, no. 4 (134), pp. 13-23.

29. Berestova L.I., Yaroslavtseva T.A. Sotsialnaya politika i sotsialno-ekonomicheskaya zashchishchennost mnogodetnykh semey v regionakh Dalnego Vostoka [Social policy and socio-economic protection of large families in the regions of the Far East]. Vlast $i$ upravlenie na Vostoke Rossii, 2016, no. 4 (77), pp. 62-75.

30. Novoselova E.N. Ravenstvo institutov semi i gosudarstva kak neobkhodimoe uslovie preodoleniya globalnogo demograficheskogo krizisa [Equality of family and state institutions as a necessary condition for overcoming the global demographic crisis]. Vestnik Moskovskogo universiteta. Seriya 18. Sotsiologiya $i$ politologiya, 2014, no. 2, pp. 108-118.

31. Nemova O.A., Vagin D.Yu., Trostin V.L. Rossiyskaya semya na poroge novogo desyatiletiya - problemy i varianty razvitiya [The Russian family on the threshold of a new decade-problems and development options]. Problemy sovremennogo pedagogicheskogo obrazovaniya, 2019, no. 65-2, pp. 193-195.

32. Pyanov A.I. Semya kak obekt i predmet sotsiologicheskogo analiza [Family as an object and subject of sociological analysis]. Izvestiya Rossiyskogo gosudarstvennogo pedagogicheskogo universiteta im. A.I. Gertsena, 2011, no. 132, pp. 164-179.

33. Shikhova E.P. Novye mezhdistsiplinarnye aktsenty v sotsiologii: semya na etape ozhidaniya rebenka [New interdisciplinary accents in sociology: the family at the stage of waiting for a child]. Vestnik Tikhookeanskogo gosudarstvennogo universiteta, 2015, no. 1 (36), pp. 287-294.

34. Ukaz Prezidenta RF ot 09.10.2007 N 1351 (red. ot 01.07.2014) «Ob utverzhdenii Kontseptsii demograficheskoy politiki Rossiyskoy Federatsii na period do 2025 goda» [Decree of the President of the Russian Federation of 09.10.2007 No 1351 (ed. of 01.07.2014) «On approval of the Concept of Demographic Policy of the Russian Federation for the period up to 2025»]. KonsultantPlyus. Avaolable at: http://www.consultant.ru/document/cons_doc_LAW_71673/(accessed 3 January 2021).

35. Bartul E.S. Issledovanie supruzheskikh konfliktov na raznykh etapakh zhiznennogo tsikla semi [Study of marital conflicts at different stages of the family life cycle]. Mezhdunarodny studencheskiy nauchny vestnik, 2019, no. 4. Available at: http://eduherald.ru/ru/article/view?id=19693 (accessed 3 January 2021).

Received: 6 January 2021. 